\title{
RHETORIC: A THEORY OF POLITICAL LIE OR THE ESSENCE OF POLITICS? REFLECTIONS ON THE THOUGHT OF THE SOPHISTS, HANNAH ARENDT, AND JACQUES DERRIDA
}

\author{
A man who himself does not believe what he \\ tells another ... has even less worth than if he \\ were a mere thing. \\ Immanuel Kant, Doctrine of Virtue
}

\begin{abstract}
This paper offers an outline of practical and theoretical relations between truth and rhetoric. A point of departure for considerations to follow are philosophical theories of the sophists, Plato, and Aristotle as well as modern commentators of political rhetoric. I argue that the predominantly rhetorical nature of contemporary culture is inextricably bound up with the controversial issue of political deception, its definition and function. I refer to the theories of Hannah Arendt and Jacques Derrida pertaining to the following issues: a relation between acting and lying, mass deception, and self-deception in totalitarian states. I further propose that classical ethics developing from Plato, Aristotle and Kant fails as a basis for the analysis of political and social processes in democratic societies. Key to grasping these processes is rhetoricas an art of persuasion - which has nothing to do with the traditional true-false dichotomy.
\end{abstract}

Keywords: rhetoric, the sophists, relativism, political deception, totalitarianism.

\section{Introduction. A short history of destruction of truth}

Considering Kant's immense contribution to philosophical ethics, the above epigraph lends itself as a fitting starting-off point for our reflections on the issues of lying and rhetoric in democratic and non-democratic socie-

- Address for correspondence: Institute of Classical Studies, Krakowskie Przedmieście 1, 00-927 Warsaw, Poland. Email: c.mielczarski@uw.edu.pl. 
ties/states in our times. Influential in the shaping of $19^{\text {th }}$-century idealism, Kant and Hegel were in agreement that telling untruth is fundamentally antithetical to human nature. Such unequivocal commitment to truth-telling was dominant in all European schools. German idealism, following from Platonic tradition, heavily influenced the European education of its day. Notably, Mickiewicz's and Słowacki's upbringing was strongly shaped and defined by Platonic ideals. Furthermore, German philosophers attempted to rethink central concepts of orthodox Platonism in terms of the cultural assumptions of that era. In a nutshell, as in Plato, the quest for the truth became the essence and purpose of philosophical education as well as general humanistic paideia. The above-mentioned philosophical tradition shaped in the times of Kant, Hegel as well as in the second half of $19^{\text {th }}$ century. In any case is still shaping our colloquial ideas about lies. So it seems that we should consider whether this traditional ethical discourse today really reflects the essence of the problem of political lies, especially regarding the relation of lying and totalitarian government. Therefore, in my opinion, it is a duty to briefly indicate an alternative tradition rhetoric. And this is my humble goal in this paper. The views of Hannah Arendt and Jacques Derrida on the essence of lie will help to show this question.

When at the turn of the $19^{\text {th }}$ century Friedrich Nietzsche questioned the existence of truth, whilst exposing the Socratic and Christian roots of European nihilism, conservative commentators disclaimed him as a misguided heretic. Nietzsche claimed that a fetishisation of objective rational truth was a token of cultural demise. For true culture depends for its existence on a purely individualistic human ability to shape his/her own interpretation of the world: one that might fly in the face of accepted notions of truth. It is thus interpretation, as opposed to truth, that is key to grasping the core of Nietzsche's philosophy, who will forever go down in history as the forerunner of European relativism. Nevertheless, most historians of philosophy agree that this view is doxographically untenable. In fact, a systematic destruction of the notion of truth was already under way in ancient times in a cultural climate that is currently championed by the social liberals as a political and spiritual cornerstone of the European legacy, that is, the culture of Athenian democracy flourishing during the lifetime of Pericles and Socrates. The open society of Athens ${ }^{1}$, nurtured on the notions of equality and freedom, attracted a group of sages called the sophists: a new breed of teachers advocating the premise that truth is inherently relative. One of these teachers was a friend of Pericles, namely Protagoras, who coined the famous homo-mensura theory:

Man is the measure of all things: of the things that are, that they are, of the things that are not, that they are not. $^{2}$

According to this principle, man arbitrates on the existence and non-existence of all things. In modern terms, the totality of human experience, both practical

' This notion, as understood in the context of Athenian democracy, was coined by K. Popper, The Open Society and its Enemies.

${ }^{2}$ See Sextus Empiricus, Adversus mathematicos [Against the Professors] VII, 60, Plato, Theaetetus 151e152a \& Diogenes Laertios, Lives of the Eminent Philosophers IX, 51. 
and symbolic ${ }^{1}$, all things material and immaterial are relative to human apprehension. Needless to say, this statement is anti-fundamentalist, and it is so understood by present-day proponents of cultural pluralism. Protagoras thought that the oppositional notions of good and evil are relative in virtue of the fact that what for some is good, others may consider evil. Moreover, his followers claimed that what may be beneficial for some may also bring harm to others. If the philosophy of the sophists laid the foundations of European pragmatism, utilitarianism and ethical conventionalism, it is also deeply relativistic. A thorough ontological and ethical analysis of the doctrines of the early sophists (Protagoras, Antiphon) makes evident that in keeping with the principle of homo-mensura every judgement is justified by virtue of its being uttered by an individual. Consequently, this principle can legitimise the veracity of every statement, even one universally considered as untrue. For this reason, the sophists have traditionally been dismissed as inconsequential sages, who play with words and serious notions.

In modern times the anthropology of the sophists and theory of rhetoric understood as a basis of interpersonal relations have been undergoing a renaissance of sorts ${ }^{2}$. The sophists proposed that it is impossible to extricate rhetoric from human interactions. They defined rhetoric as an art of persuasion that is germane to human existence in a state community. Gorgias postulated that to succeed in rhetoric, and by implication in life, what one says must be appropriate to the occasion. He promoted the notion of kairós, meaning the right moment ${ }^{3}$. He went on to argue that to excel in rhetoric one should master the skill of argumentation. Arguments should be appropriate to the context of speaking including place, time and audience. This theory was later taken on board by Aristotle, whose theory of argumentation remains an authoritative source on the theory of rhetoric ${ }^{4}$. However, in his famous opening to book I of the Politics (I 1253, 7-15), Aristotle, whilst stressing the unique role of a human being as a political animal endowed with speech, maintains that speech should help one distinguish between good and evil, justice and unfairness. If speech is an art of persuasion, one should use it as a force for good and justice, as he further proposes in his Rhetoric. However, we must emphasise that Aristotle consistently undermines this noble statement, detailing deceptive rhetorical practices $^{5}$. And yet the political and rhetorical theory of the teacher of humanity

${ }^{1}$ When I use the concept of symbolic human experience, I refer to the thought of Ernst Cassirer, who assumed that human being as an animal symbolicum lives in a symbolic world. See E. Cassirer, Essay on Man, p. 25: [...] man lives in a symbolic universe. Language, myth, art and religion are parts of this universe. They are the varied threads which weave the symbolic net, the tangled web of human experience. See also the chapter $A$ Clue to the Nature of Man: The Symbol.

${ }^{2}$ See G. B. Kerferd (ed.), The Sophists and their Legacy.

${ }^{3}$ See a theoretical outline of the term kairós in J. L. Kinneavy, Kairos in Classical and Modern Rhetorical Theory \& J. L. Kinneavy, Kairos: A neglected concept in classical rhetoric.

${ }^{4}$ Ch. Perelman's The New Rhetoric draws heavily on the Aristotelian tradition. See Ch. Perelman \& L. Olbrechts-Tyteca, Traité de l'argumentation.

${ }^{5}$ See R. Wardy, Mighty Is the Truth, and It Shall Prevail? Wardy is showing that Aristotle often describes the art of persuasion as an art which subordinates truth to pragmatic victory. 
(as hailed by $\mathrm{Hegel}^{1}$ ) is based on the theory of the common good. Aristotle as before Isocrates stressed that logos addresses areas of uncertainty in which the truth simply cannot be known or found. So their dependence on the sophists is obvious $^{2}$. Aristotle in his rhetorical theory is focused on judgement and on probability - rhetoric does not provide knowledge of the truth; the orator guides judgment, i.e. seeks the available ways and means of persuasion. Therefore, it is a big question if we should consider Aristotle's theory in terms of the true/false opposition.

\section{Rhetoric and truth}

According to Plato Gorgias thought that true wisdom came from political valour (areté), the ability to influence others verbally ${ }^{3}$. His theory inspires the question that continues to absorb many a rhetorician: should the speaker's words be considered under the rubrics of the true-false dichotomy? This question is relevant for grasping the essence of political democracy, which according to Plato makes no claim for truth, as it is based on assumptions rather than knowledge ${ }^{4}$. The University of Warsaw has recently hosted a professional counsellor in political rhetoric, who has composed speeches for prominent political figures ${ }^{5}$. After delivering his insightful speech on the techniques of seducing the audience with pathos and ethos, he was asked about the role of truth in political speech and to what extent politicians depend on truth when addressing their followers or opponents. His answer echoed Pontius Pilate's famous response to Jesus: What is truth ${ }^{6}$ The expert on political marketing later admitted that a politician must be first and foremost persuasive: a trait that cannot be reduced to the tight true/false categories.

Since antiquity, the rhetorical pragmatism of the sophists has been dismissed by the great philosophical tradition originating from Plato and Aristotle, who insisted that truth and truthfulness are paramount in human life. However, Plato's standpoint on this was far from radical - he was prepared to accept deception, providing it was politically justified or useful. Aristotle, on the other hand, was adamant that telling untruth is unconditionally wrong and reprehensible, no matter how noble the purpose may be, and that consequently truth is morally right and exemplary. One should always tell the truth irrespective of the circumstances, especially when one has a vested interest in the given cause ${ }^{7}$. Truth-telling is thus a token of the ethical integrity of the speaker. It is possible that Aristotle's strong position on truth was a critical

\footnotetext{
${ }^{1}$ See G. W. Hegel, Vorlesungen über die Geschichte der Philosophie, vol. 2, p. 144.

${ }^{2}$ See Isocrates, Antidosis, 271.

${ }^{3}$ See Plato, Gorgias 452e.

${ }^{4}$ See Plato, Gorgias 452d-453a.

${ }^{5}$ Simon Lancaster, the former speech-writer of the Labour Party, working also for the former British Prime Minister Tony Blair, delivered the speech: Winning minds. Secrets from the language of leadership (University of Warsaw, Apr. 7, 2016).

${ }^{6}$ Evangelium Secundum Ioannem 18, 38.

${ }^{7}$ See Aristotle, Politics $1127 \mathrm{a}-\mathrm{b}$.
} 
response to Socrates' provisional acceptance of political deception. According to Plato, Socrates conceded that rulers were justified in lying to their enemies as well as citizens for the common good ${ }^{1}$. This is referred to as the righteous lie theory: one that permits deception if the common good is at stake. This is to imply that manipulating truth may be permissible when governing a community for the greater good and general well-being of the community. It is evident that this premise fails to address the basic question: what is the common good? Undoubtedly, it is a philosophical and political issue - as regards both political theory and practice. The answers will differ according to the varying notions of what counts as good for the community, regardless of the political system it is governed by - be it democracy or otherwise. Plato's defence of political deception is predicated on the assumption that the rulers know what is good for the people, whereas the public lack the knowledge or experience to judge what is good for them. In addition, such a political deception is acceptable, because only the politician, who should be primarily philosopher, can have an absolute knowledge of the mind of God, who decides what is good for people and state. This view is connected with Plato's distrust of the masses, who - governed by passions rather than the sense of common good - should not be given a mandate to decide on political matters. This is consistent with Plato's view of democracy as the worst possible political system, which is inherently antithetical to truth.

Of course, we cannot ignore the concept of rhetoric presented by Plato in the Phaedrus, because in antiquity and in later times this concept was treated as an opposition to sophisticated and deceptive eristicism. In this dialogue, Plato explicitly implies that real rhetoric (i.e. politics) is all about telling the truth the goal is to guide souls. If someone does not know the truth in any matter, he should not deal with rhetoric. So a good orator/politician could only be a philosopher. It is obvious that such a theory of rhetoric cannot be credible, because the sophists had already argued that everyone recognises the truth as something different. In fact, Platonic rhetoric is nothing more than a dialectic in that matter the cognitive effects cannot be commonly and intellectually considered as lies, because dialectic is rather philosophy and not rhetoric.

\section{Place of rhetoric in antiquity and in sequent ages}

The sophists revolutionised education, because from their times on rhetoric became the compulsory subject in Greek and later in Roman schools. Aristotle proposed that if making and rejecting judgements is what people normally do, everyone should practise some form of dialectics: an inquiry into contradictions, and rhetoric, an art of persuasion ${ }^{2}$. Classical rhetoric would dominate school curricula across all periods until the Enlightenment. The $19^{\text {th }}$-century Romanticism and idealism were influential in undermining the central position of rhetoric at schools. This shift was made possible by rethinking of the classical tradition amongst intellectual elites when German idealism was beginning to gain ground. The concept of Bildung, coined by Humboldt and his followers,

\footnotetext{
${ }^{1}$ See Plato, Respublica 389b-c.

${ }^{2}$ Aristotle, Rhetoric 1354a.
} 
was based on the cult of spiritual virtues of classical culture rather than on the pragmatism of rhetoric. This period was strongly defined by idealistic education influenced by Plato. On Polish territory Mickiewicz's and Słowacki's preoccupation with classical literature and philosophy was by no means inspired by the need to master the skill of rhetorical persuasion to influence people. They reached for the old masters to infuse their poetry with spirit and emotions rather than to learn how to argue persuasively.

The modern exponents of rhetorical studies draw on Aristotle by arguing that as a social animal a human being engages in acts of communication. They would go as far as to state that society cannot fully operate without some forms of verbal and non-verbal communication. People use body language and verbal expressions in order to influence or persuade others. Such communicative skills are imperative for members of a community to fulfil their social and professional roles. Public trust can only be earned through respect, and respect can be won by exerting one's influence on others.

The period of the $20^{\text {th }}$ century marks a revival of rhetorical studies in their many iterations, be they philosophy, theory or social practice. This trend is most pronounced in the USA, where the teaching of rhetoric has a long-standing tradition in education. Instrumental in shaping both individual and collective expression, rhetoric is part and parcel of university education. Associated with politics, rhetoric is commonly understood as a skill used to galvanize the public rather than as an art of fine speech, whose sublime aesthetics are intended to impress them. It is important to note that our post-modern culture is being shaped by the increasingly influential art of verbal (but also aural and visual) persuasion. The $20^{\text {th }}$ century was a period of rethinking of traditional understanding of the art of persuasion in culture, education and customs. This also applies to both humanities and sciences. The shift included a departure from the traditional notion of persuasion conceived as a negative skill orientated at exercising the speaker's influence over others - one that was pervasive in ancient culture. Such a skill was often dismissed in Platonic terms as a violation of truth, which sparked a wide prejudice against the sophists as teachers of mere verbal tricks as opposed to true knowledge. This low regard of rhetoric persisted despite the efforts of Renaissance humanist scholars to raise the status and value of verbal expression, rhetoric and urban manners ${ }^{1}$.

Despite the efforts, the sophists would continue to be regarded as advocates of negative values associated with the refined and effective, yet misleading, rhetoric that was antithetical to truth: rhetoric that is predicated on the subversive, if persuasive, use of words and body language. To exemplify, in Milton's Paradise Lost Belial is one of the most convincing fallen angels. And yet, for all his fancy rhetoric, his feigned courage, charm and dignity are exposed:

[...] On th' other side up rose

Belial, in act more graceful and humane;

A fairer person lost not Heav'n; he seemd

For dignity compos'd and high exploit:

\footnotetext{
${ }^{1}$ See P. O. Kristeller, The Humanistic Movement.
} 
But all was false and hollow; though his Tongue

Dropt Manna, and could make the worse appear

The better reason, to perplex and dash

Maturest Counsels: for his thoughts were low;

To vice industrious, but to Nobler deeds

Timorous and slothful: yet he pleas'd the ear,

And with persuasive accent thus began. ${ }^{1}$

Belial is unmistakably presented here as a sophist, who, although his thoughts were low, is capable of making the worse appear the better (as was Protagoras alleged to have preached $)^{2}$. Milton's references to the sophistic rhetoric seem to be inspired by the spirit of the $17^{\text {th }}$-century English political landscape: one of a flourishing of political speech. Milton was, after all, a close ally and supporter of Oliver Cromwell, a prominent speaker, a towering political figure of the age and leader of the Parliamentarians against Charles I during the English Civil War.

\section{Opposition between philosophy and sophistic}

The uncontested dominance of Aristotelian philosophy at schools and universities until the $18^{\text {th }}$ century diminished the positive reception of sophistic philosophy. Tensions between philosophy and sophism alongside the strong influence of anti-relativistic epistemology and ethics significantly diminished a scholarly interest in sophism as well as the role it played in the history of European thought. Although education was still dominated by the Socratic and Platonic tradition, the reception of the sophistic philosophy was beginning to alter in the $19^{\text {th }}$ century. This may well be attested by Hegel, who claimed that sophists contributed immensely to the formation of European thought ${ }^{3}$. Along these lines, Hegel observed that the sophists helped redefine Greek culture by rendering it more rational ${ }^{4}$. In such a culture, problems and issues should be considered from multiple and competing points of view. This was how Hegel understood the didactic relativism of the sophists. However, this was also precisely the reason why Hegel refused to grant the sophists the status of philosophers. They, after all, promote formal education ${ }^{5}$. The German philosopher prefers to call it kind of education culture in opposition to philosophy. Whereas the purpose of philosophy is to discover truth, culture is merely an elaborate way of accepting certain assumptions/opinions/convictions. If this quality is what renders culture alluring, it also makes good, beauty and truth arbitrary ${ }^{6}$. By promoting this distinction, Hegel proved his indebtedness to Platonic

\footnotetext{
${ }^{1}$ John Milton, Paradise Lost II, 108-118.

${ }^{2}$ Aristotle, Rhetoric 1402a. However, we cannot forget that Socrates was also accused of the same (see Plato, Apology).

${ }^{3}$ Hegel provides a positive assessment of the legacy of sophists in his Vorlesungen über die Geschichte der Philosophie, vol. 1, pp. 519-559.

${ }^{4}$ G. W. Hegel, Vorlesungen über die Geschichte der Philosophie, vol. 1, pp. 523-525.

${ }^{5}$ G. W. Hegel, Vorlesungen über die Geschichte der Philosophie, vol. 1, p. 544.

${ }^{6}$ G. W. Hegel, Vorlesungen über die Geschichte der Philosophie, vol. 1, p. 538.
} 
ontology and later philosophical tradition that sought to tell apart philosophy and sophistry.

It can be argued that Hegel proposed that education and culture threaten normative notions of truth in that educated people know how to manipulate others using rhetorical skills when making their case for an argument. And in so doing they pander to sophistry. Reading Hegel, it becomes clear why Plato consistently challenged the comparative strategies of obtaining knowledge nurtured by the sophists, which, he argued, did not merit the status of proper education. Hegel's foregrounding of the opposition of culture and philosophy derives from the Platonic tradition that is strongly hostile to sophism. This opposition is an archetype of universal ideological discourse as a site of contestation between tradition and innovation, between scepticism, intellectual, political and creative freedom, and philosophical and cultural norms as well as other defining human values ${ }^{1}$. According to the proponents of conservative schools of thought, to repudiate these principles is to threaten the foundations of humanity and human society as a whole. The earliest and most prominent example of this sort of opposition in European culture was the ideological and doctrinal disagreement between Plato and the sophists. As proposed by Cassirer, the shaping of civilisation depends on human liberation from the norms of the symbolic culture. This thesis has been confirmed by recent scholarship in the social sciences.

\section{Relativism of modern thought}

When listing major influences in contemporary philosophy and humanities, it is hard to overlook the fact that the most widely-discussed and provocative schools of thought are those that call into question the notion of objective truth. Amongst the most notable are: postmodern philosophical theories, American Neo-Pragmatism, Habermas's social dialogue theory, Kuhn's theory of scientific revolutions, Perelman's New Rhetoric, and the new theories of literary interpretation - the so-called Reader-Response Criticism, with Stanley Fish as a key figure. In his works Fish argues that since people inhabit a given social space and culture, which shape their subjective cognitive criteria, objective hermeneutic truth as registered in literature, philosophy and culture does not exist. The ways in which we view culture and the world are based on specific cultural, cognitive and professional - that is broadly political ideology. In other words, our interpretations are moulded by the local cultural context in which we happen to live. As a result, our understanding of the world is situational, conventional, and local. In addition, Fish proves that rhetoric underlies epistemology ${ }^{2}$.

In the postmodernist theory the human being is a homo politicus who lives to develop adaptive skills that secure his position in a given environment rather

\footnotetext{
${ }^{1}$ According to Ernst Cassirer this contention is inherent in cultural processes. See E. Cassirer, An Essay on Man, p. 224. See also p. 228.

${ }^{2}$ This contention explores G. Olson, Justifying Belief.
} 
than acquiring knowledge for its own sake ${ }^{1}$. The skill of persuasion is thus a natural instrument that helps one operate properly in society. Some proponents of this theory argue that education should focus on strengthening one's position and power in society ${ }^{2}$. In the light of this theory of education the notion of truth is controversial, if not anti-philosophical. The conservatively-minded thinkers claim that such social education is based on epistemological, ethical and social relativism, which is a marker of cultural demise (e.g. Leo Strauss, Eric Voegelin, Allan Bloom).

The construction of truth as a political term is currently studied by scholars of communication theory, who champion rhetoric as a scholarly field that informs the nature of human relationships. The leading exponent in this field is Michael Calvin McGee, who coined the notion of ideograph ${ }^{3}$. Ideographs denote values or concepts - often competing or indefinite - employed by politicians to persuade the public to accept their political persuasions or views (such as liberty, equality, human rights, patriotism, etc.). They are words and phrases circulating in public discourse that serve to seduce people or strengthen the ideological position of politicians and their parties. Therefore, political and rhetorical criticism should investigate the use of abstract concepts in political narratives that constitute political ideologies. These concepts are a basic tool of engaging the public politically. They epitomise and sanction the political decisions made by politicians on behalf of the public ${ }^{4}$. As such, they function as slogans and political labels that represent an ideology in the social space: often employed to counter social groups and political opponents that espouse competing views and ideologies. But ideographs can also operate outside of the political domain in fields such as advertising and marketing. Since all of these cultural domains depend on persuasion for their operation, they rest on certain ideologies, which may or may not be political. Ideology is, after all, an interpretation of basic linguistic terms that structure our personal and social life. In the field of political philosophy, the best-known attempt to solve the problem of contradictory ideologies is the theory of John Rawls, who created and developed the concept of overlapping consensus:

[...] justification is addressed to others who disagree with us, and therefore it must always proceed from some consensus, that is from premises that we and others publicly recognize as true; or better, publicly recognized as acceptable to us for the purpose of establishing a working agreement on the fundamental questions of political justice. ${ }^{5}$

${ }^{1}$ R. Amossy, The Functions of Polemical Discourse in the Public Sphere, analysing the essence of antithetical, non-truth-based rhetoric also refers to postmodern paideia based upon similar assumptions.

${ }^{2}$ See H. A. Giroux, Theories of Reproduction and Resistance in the New Sociology of Education ... .

${ }^{3}$ See M. C. McGee, The 'ideograph': A link between rhetoric and ideology.

${ }^{4}$ See e.g. C. M. Condit \& J. L. Lucaites, Crafting equality ... , pp. XXII-XXIII.

${ }^{5}$ J. Rawls, Collected Papers, p. 394. See also J. Rawls, The Idea of an Overlapping Consensus. 
In fact, overlaping consensus is the basic philosophical concept in Rawls' famous theory of justice as fairness. It must be remembered that the whole of his philosophy and also communication theory of Habermas is a practical attempt to overthrow ideologies in democratic politics and social communication.

McGee argues that the contending interpretations of ideographs create social rifts which result from political processes and cultural transformations. Are there, then, social conditions in which we could consider these competing interpretations in terms of the truth-lie? Key to understanding the diverse ways in which individuals and societies operate is a rhetorical and historical analysis of central linguistic terms commonly used in the political domain or outside of it. Politics is thus a sort of un/conscious game based on familiar values widely accepted by the general public, majority or masses (rather dismissively referred to by Plato as hoi polloi). A rhetorical analysis of ideographs facilitates an interpretation of these values in a specific context, intentions of the speaker/politician and meaning of the terms he or she uses. The main goal of rhetorical methodology is therefore to expose the underlying meanings of concepts used for ideological purposes. An ideological analysis should not depend entirely on a historical interpretation of a given concept, semantic trope or myth (I refer to these terms in the context of Nietzsche's understanding of language as a repository of metaphors or semantic tropes, which are considered as truth ${ }^{1}$ ). Ideological concepts are implicated in all aspects of human performance. The performative quality of ideographs is rhetorical inasmuch as every free individual or collective act involves some degree of rhetorical persuasion. A philosophy that properly addresses various aspects of human experience must not overlook the role that persuasion plays in human life. All human activity, including the political, depends on communicating ideas that help legitimise a given action. These ideas are often conceived to deprecate the achievements both material and symbolic - of opposing individuals or organisations.

\section{Arendt's and Derrida's views on lie}

According to Hannah Arendt, a defining characteristic of human action is its propensity for novelty. The active subject must create individual space in which to act, which may involve a rejection of previous values or systems occupying this space ${ }^{2}$. On the one hand, this usurpation is an affirmation of personal truth intended to justify one's personal action. But it is also a given that an affirmative action is usually shaped by a tradition that precedes it. The lie is thus a rhetorical act meted out to those whom the members of a competing political camp attempt to oust from the public space. To expose such prevarication, one must examine the text and local context of a statement if political

${ }^{1}$ See F. Nietzsche, Über Wahrheit und Lüge im aussermoralischen Sinne, p. 882: Was ist also Wahrheit? Ein bewegliches Heer von Metaphern. Metonymien. Anthropomorphismen kurz eine Summe von menschen Relationen, die, poetisch und rhetorisch gesteigert, übertragen, gesmückt wurden, und die nach langem Gebrauche einem Volke fest, canonisch und verbindlich dünken: die Wahrheiten sind Illusionen, von denen man vergessen hat, dass sie welche sind, Methafern, die abgenutz und sinnlich kraftlos geworden sind.

${ }^{2}$ See H. Arendt, Lying in Politics: Reflections in The Pentagon Papers, p. 35. 
concepts depend on local circumstances of the statement as well as the ethos of the speaker.

In 1997 Jacques Derrida came to Warsaw to deliver a lecture on the history of the (political) lie $^{1}$. The choice of the subject was hardly accidental. After all, Poland had just recovered from a tyranny of mass deception infiltrating all social areas. It is common knowledge that the Communist regime employed both elaborate and crude forms of political rhetoric. In the country where freedom of speech was systematically curbed, ways in which to investigate or delegitimise this rhetoric were unavailable. Derrida was in agreement with Hannah Arendt on the issue of the political lie:

Arendt sketches a problematic of the performativity of a lie whose structure and event would be linked in an essential manner to the concept of action and, more precisely, political action. She often recalls that the liar is a 'man of action,' I would even add: par excellence. Between lying and acting, acting in politics, manifesting one's own freedom through action, transforming facts, anticipating the future, there is something like an essential affinity. ${ }^{2}$

What is more, Derrida claimed that unless the lie and its effects are treated as symptoms of human culture, they will never be identified as such. Therefore, the logic of the symptom can no longer be contained within an opposition between good faith and bad faith, the intentional and the nonintentional, the voluntary and the involuntary, and so forth - in short, the lie. ${ }^{3}$

The main thrust of Derrida's argument is that as long as in democratic societies truth remains indeterminate, prevarication should not be equated with lying. However, according to Protagoras' homo-mensura principle individuals are free to make individual judgements which may contradict the views of others. In much the same vein, Wilhelm Dilthey, who coined the world-view theory, assumed that culture is determined by countless ideologies ${ }^{4}$. And it is hardly controversial to state that in a free society every human action reflects our subjective viewpoints and attitudes. So configured, a total of human activity in its vast diversity resists the strict confines of the true-false dichotomy. This insight seems particularly relevant in politics in that it legitimises the relative nature of the political lie. For Derrida the lie emerges from violence that derives from the moment in which human acts turn into a universal and unassailable law. So understood, the lie is a performative act in that it stems from a political action.

\footnotetext{
${ }^{1}$ The lecture was delivered at The Zachęta National Gallery of Art, on Dec. 17, 1997. The speech was later published in French in a special issue on Derrida: Cahier de l'Herne 2004.

${ }^{2}$ J. Derrida, History of the Lie: Prolegomena, p. 66.

${ }^{3}$ J. Derrida, History of the Lie: Prolegomena, pp. 68-69.

${ }^{4}$ Dilthey's world view theory is elucidated in his Das Wesen der Philosophie [1907] and Die Typen der Weltanschauung und ihre Ausbildung in den metaphysischen Systemen [1911].
} 


\section{Classical ethics and political lie - Derrida's and Arendt's reflections}

Should one accept Protagoras' assumption that truth is what appears to each individual as truth, it is uncertain whether any political views can be dismissed as untrue. This is a pressing and complex issue. The complexity of lying, and its cultural impact, has been addressed by many a philosophical work, created in different epochs. Regarding the essence of rhetoric as an art of the lie we should start our discussion from the times of Athenian democracy. In Plato's Hippias Minor ${ }^{1}$, Socrates speaks to Hippias about the benefits of prevaricating or misguiding others. To exemplify this, they discuss two iconic Homeric heroes: Achilles - a truthful warrior who despises liars; and Odysseus, a symbol of cunning, deception and resourcefulness. Although his behaviour was at odds with ethical standards of Greek aristocracy, Odysseus, whose success depended on deception, was universally admired in the Hellenic world as a model hero. At this point Socrates mocks Hippias for his admiration of these questionable virtues of the Greek hero. After all, both participants of the dialogue agree that Odysseus benefited from the lies he told wilfully. This inspires Socrates to ask a provocative question: should the Hellenic hero be considered as a role model at all? The subversive character of this universal ethical dilemma is pertinent in the context of politics.

Contemplating various challenges in defining the notion of a lie, Derrida refers to the great tradition of classical ethics. He mentions St Augustine, who proposed that a liar resorts to various underhand practices in order to misguide the other, including telling the truth. Consequently, it is possible to tell untruth and yet avoid lying, providing the deception is unintentional and that the speaker truly believes his or her words to be true. Conversely, it is possible to tell the truth to deceive somebody: and this is a sheer lie. St Augustine states in no uncertain terms that if one believes in his or her words, he or she does not lie even if the words are untrue ${ }^{2}$. This speculation is of supreme importance in considering the responsibility of people who are involuntarily involved in war atrocities or other political crimes. Is the person liable for the committed crimes when he carries out a command which is based on a political deception? Should one accept such extenuating circumstances, then it is legitimate to acquit all war criminals condemned for their crimes. The trial of Adolf Eichmann that took place in Jerusalem presented itself as an occasion for Hannah Arendt to contemplate the controversial issue of the convict's blind obedience to his nation and its leader, which for Eichmann was an ethical duty of utmost importance and a cause for personal pride.

Another thinker quoted by Derrida is Aristotle, who claimed that a liar is one who chooses to lie rather than tell the truth. Although a liar knows the truth, $\mathrm{s}$ /he conceals, ignores, misrepresents, or denies it. In other words, a liar wilfully constructs his or her own false reality. A conscious liar is thus worse that one who tells untruth involuntarily. But there is a caveat here. Should the latter be dismissed as a liar at all if $\mathrm{s} / \mathrm{h}$ is unaware of telling a lie? This question needs

\footnotetext{
${ }^{1}$ This dialogue is subtitled as: è perì toû pseúdous, which translates as on the lie. This translation is, however, imprecise in that in Greek pseûdos may refer not only to a lie, but also to deception, trick, false teachings.

${ }^{2}$ St. Augustine, De mendacio, I, 3, 3. Quoted after: J. Derrida, History of the Lie: Prolegomena, p. 31.
} 
repositioning if discussed in the context of $20^{\text {th }}$-century totalitarian regimes which fed (and still do) on mass deception. It is common knowledge that a totalitarian regime enforces on its subjects unconditional adherence to its dominant ideology disseminated via national propaganda machine. Accepting that the subjects are forced to accept narratives promoted by the state authorities, this makes it questionable whether they can be referred to as liars at all. One also needs to consider the problem of self-deception, or else political selfsuggestion, which influences the public opinion as well as individual choices of the citizens. Along these lines, Hannah Arendt discusses the absolute lie, characteristic of the $20^{\text {th }}$-century totalitarianism ${ }^{1}$. This variety of lie differs from a traditional understanding of deception. Thus,

[...] the difference between the traditional lie and the modern lie will more often than not amount to the difference between hiding and destroying. Moreover, the traditional lie concerned only particulars and was never meant to deceive literally everybody; it was directed at the enemy and was meant to deceive only him. $^{2}$

If our sense of reality is determined by the people in our immediate surroundings, collective self-deception is central for legitimising closed states (or political parties). By accepting dominant narratives, the public submit to social constructs that are patently untrue. This so-called herd mentality is what defines political communities ${ }^{3}$. At this point, Derrida takes issue with Hannah Arendt's psychological concept of self-deception:

Now, such a concept remains confused in the "psychology" it implies. It is also logically incompatible with the rigor of any classical concept of the lie and with the "frank" problematic of the lie. To lie will always mean to deceive the other intentionally and consciously, while knowing what it is that one is deliberately hiding, therefore while not lying to oneself. And the addressee must be other enough to be, at the moment of the lie, an enemy to be deceived in his belief. The self, if this word has a sense, excludes the self-lie. ${ }^{4}$

With this in mind may we ask whether do totalitarian societies, which feed off collective lies, fall victim to self-deception? If not, one would have to concede that Adolf Hitler, who ardently believed in his cause, acted in good faith. One would be hard-pressed to deny that he really was convinced that the extermination of Jews was necessary for the greater good of all humanity. His moral

\footnotetext{
${ }^{1}$ See H. Arendt, Between Past and Future, p. 248.

${ }^{2}$ H. Arendt, Between Past and Future, p. 304.

${ }^{3}$ Modern psychology and social science have consistently emphasised that the human psyche and social behaviour are heavily influenced by culture and politics. The same territory is explored in many modern literary works, such as C. Miłosz's The Captive Mind or George Orwell's Nineteen Eighty-Four, amongst the most notable examples.

${ }^{4}$ J. Derrida, History of the Lie: Prolegomena, p. 67.
} 
and political fallacy could thus be put down to his failure to conform to commonly respected European values, which, to his mind, were detrimental to the national interests of Germany. Following this line of thought, one would have to admit that for all the unimaginable monstrosity he committed, Hitler might have endorsed and committed to a fallacy, but did not lie.

\section{Conclusion}

Those who think that democracy marks the end of ideology have been proven wrong, although, admittedly, democracy does contradict totalitarianism. Social and cultural heterogeneity characteristic of democratic states has failed to obliterate ideological, so to speak, boundaries between people. This raises a question of whether these ideologies, in all their manifestations, should be regarded as political lies. Ideology relies for its effects of rhetorical persuasion on the use of words, whose meaning can be grasped by an analysis of rhetorical strategies of manipulation. Consequently, in Western countries rhetorical studies has become a prominent academic discipline which prioritises an unbiased analysis of political content. Arguably, this discipline should be a basis for the study of how societies operate in a given place and time. Considering the present cultural fashions, political analysis cannot be explained solely by the classical ethics of Plato, Aristotle and Kant. Central to grasping the political and social logic of democracy is rhetoric, which cannot be researched by criteria based on strict true-false opposition. Plato was right after all: democracy is defined by assumptions and beliefs (dóxai) enforced, as we could say nowadays, by political, social and economic units, on social groups.

The ways in which institutions, units or organisations influence human behaviour and attitudes using strategies of persuasion should become a subject of comprehensive general education in democratic societies (of course I also mean media literacy). This model of education is in demand in societies which nurture the culture of tolerance and respect for otherness. With this in mind, current research on the cultural influences of rhetorical devices must by default depend on an analysis of social mechanisms with the use of latest research from across multiple disciplines: (social) philosophy, social science, psychology, and communication theory. And yet, given that this interdisciplinary research involves the study of persuasion and its influence on human behaviour, rhetorical studies considerably complement its findings. One of central preoccupations of rhetorical studies is an analysis of ancient models of the art of persuasion and their impact on contemporary cultural experience. Apparently, modern democratic societies seem to draw heavily on the achievements of ancient theory and practice as well as rhetoric. A notable example of this cultural renaissance of antiquity is a rereading of Aristotle's art of argumentation by the $20^{\text {th }}$-century philosopher of law, Chaim Perelman ${ }^{1}$. On the other hand, we must also mention here Ivor Armstrong Richards and his concept of rhetoric as the study of misunderstanding and its remedies ${ }^{2}$.

\footnotetext{
${ }^{1}$ See p. 149, n. 4.

${ }^{2}$ See I. A. Richards, The Philosophy of Rhetoric, p. 7.
} 
In democratic societies the social space is moulded by pervasive communication messages (simulacra). The reality they create, however, stakes no claims for truth - be it an absolute being (as theorised in classical epistemology), an objective event or human artefact. At this point I refer to the thought of Jean Baudrillard ${ }^{1}$. Preoccupied with the underlying logic of mass culture, Baudrillard argued that in the modern semiotic culture limits between reality and its representation collapse. In such culture, our perception of reality depends on cultural signs (that is, simulacra), which act as fabricated representations of reality. As simulacra generate other simulacra, what follows is an infinite chain of Platonic idols (eidola), which shape our cultural space. So configured, this cultural space is a form of hyper-reality which simulates truth. Our mind struggles to distinguish between reality and its simulacra. This is because reality is absorbed by its own representations, thus becoming another representation. The omnipresence of visual images, sounds and written signs has transformed the Euro-American culture into a social space moulded by facts, messages and ideologies competing for our attention. In such a cultural venue, the Platonic eidolon has become a dominant communication model of modern civilisation.

Looking into the works of the latest commentators of mass culture, such as Jean Baudrillard and René Girard, it could be reasonably argued that the vacuous and illusive representations of false reality have dominated human relations. Described by Zygmunt Bauman, the liquid modernity to a large extend is moulded by simulacra in a broad sense. But it has curiously eluded the grasp of many a commentator that the essence of simulacra is the widely understood rhetorical persuasion on which human relations in a democratic society heavily depend. This must be taken into consideration in the context of the theories of Hannah Arendt and Jacques Derrida, who turn to the principles of classical ethics - based on normative axiology - in their study of political deception. But there are stakes involved in adopting this approach to studying the mechanisms of contemporary culture given that, as observed by Richard Rorty, contemporary democratic societies fail to conform to normative philosophical standards ${ }^{2}$. It may appear, however, that political praxis flies in the face of this conjecture in that political leaders or institutions continue to claim to rely on truth. And yet, a thorough rhetorical analysis exposes the internal incongruities of such assertions, which contradict fundamental normative ethical values deriving from Plato, Aristotle and Kant.

\section{References}

Amossy R., The Functions of Polemical Discourse in the Public Sphere in: The Responsibilities of Rhetoric, (eds.) M. Smith \& B. Warnick, Waveland Press, Long Grove 2010, pp. 52-61.

Arendt H., Between Past and Future. Eight Exercises in Political Thought, Penguin Books, New York 2006.

\footnotetext{
${ }^{1} \mathrm{~J}$. Baudrillard spells out the theory of simulacrum in Simulacres et simulation.

${ }^{2}$ See R. Rorty's essay The Priority of Democracy to Philosophy.
} 
Arendt A., Lying in Politics. Reflections in The Pentagon Papers in: The New York Review of Books 17, 8/1971, pp. 30-39.

Aristotle, Politics, (ed. \& transl.) E. Barker, Oxford University Press, Oxford 1974.

Aristotle, Ars Rhetorica, (ed.) W. D. Ross, Oxford University Press, Oxford 1959.

Baudrillard J., Simulacres et simulation, Galilée, Paris 1981.

Cassirer E., An Essay on Man, Yale University Press, New Haven \& London 1998.

Condit C. M. \& Lucaites J. L., Crafting equality: America's Anglo-African word, University of Chicago Press, Chicago 1993.

Derrida J., Histoire du mensonge. Prolégomènes in: Cahier de l'Herne 200, pp. 495-521 [Engl. transl. History of the Lie: Prolegomena in: J. Derrida, Without Alibi, transl. P. Kamuf, Stanford University Press, Stanford, pp. 28-70].

Dilthey W., Das Wesen der Philosophie, Marixverlag, Wiesebaden 2008.

Dilthey W., Die Typen der Weltanschauung und ihre Ausbildung in den metaphysischen Systemen, Reichl Verlag, St. Goar 1951.

Diogenes Laertius, Lives of Prominent Philosophers, transl. R. D. Hicks, vol. 2, W. Heinemann \& Harvard University Press, London \& Cambridge, MA 1965.

Evangelium Secundum Ioannem in: Novum Testamentum Graece et Latine, (eds.) E. Nestle, K. Aland, B. Aland \& alii, Deutsche Bibelgesellschaft, Stuttgart 1979, pp. 247-319.

Giroux H. A., Theories of Reproduction and Resistance in the New Sociology of Education: A Critical Analysis in: Harvard Educational Review 53, 1983, pp. 257-293.

Hegel G. W., Vorlesungen über die Geschichte der Philosophie [1833], vol. 1 \& 2, Phillip Reclam, Leipzig 1971.

Isocrates, Antidosis in: Isocrates, vol. 2, transl. G. Norlin, W. Heinemann \& G. P. Putnam's Sons, London \& New York 1979, pp. 181-365.

Kinneavy J. L., Kairos in Classical and Modern Rhetorical Theory in: Ph. Sipiora \& J. S. Baumlin (eds.), Rhetoric and Kairos: Essays in History, Theory, and Praxis, University of New York Press, Albany 2002, pp. 5876.

Kinneavy J. L., Kairos: A neglected concept in classical rhetoric in: J. D. Moss (ed.), Rhetoric and praxis: The contribution of classical rhetoric to practical reasoning, The Catholic University of America Press, Washington DC 1986, pp. 79-105.

Kristeller P. O., The Humanistic Movement in: The Classics and Renaissance Thought, Harvard University Press, Cambridge MA 1955, pp. 3-23.

McGee M. C., The 'ideograph': A link between rhetoric and ideology in: Quarterly Journal of Speech 66, 1980, pp. 1-16.

Milosz C., The Captive Mind, transl. J. Zielonko, Penguin Books Ltd., New York 2001.

Milton J., Paradise Lost, (ed.) G. Teskey, W. W. Norton \& Co., New York 2004. 
Nietzsche F., Über Wahrheit und Lüge im aussermoralischen Sinne in: Sämtliche Werke. Kritische Studienausgabe, vol. 1, (eds.) G. Colli \& M. Montinari, W. de Gruyter, Berlin \& New York 1967, pp. 875-890.

Olson G., Justifying Belief: Stanley Fish and the Work of Rhetoric, SUNY Press, New York 2002.

Orwell G., Nineteen Eighty-Four, Penguin Books Ltd., New York 2000.

Perelman Ch. \& Olbrechts-Tyteca L., Traité de l'argumentation. La nouvelle rhétorique, PUF, Paris 1958.

Plato, Apology in: Plato, Euthyphro, Apology of Socrates, Crito, (ed.) J. Burnet, Clarendon Press, Oxford 1924.

Plato, Gorgias, (ed.) E. R. Dodds, Clarendon Press, Oxford 1990.

Plato, Respublica, (ed.) S. R. Slings, Clarendon Press, Oxford 2003.

Plato, Theaetetus in: Platonis Opera, (ed.) J. Burnet, Clarendon Press, Oxford 1967, pp. 142-210.

Popper K., The Open Society and its Enemies [1945], Princeton University Press, Princeton 2002.

Rawls J., Collected Papers, (ed.) S. Freeman, Harvard University Press, Cambridge MA \& and London 1999.

Rawls J., The Idea of an Overlapping Consensus in: Oxford Journal of Legal Studies 7, 1/1987, pp. 1-25.

Richards I. A., The Philosophy of Rhetoric, Oxford University Press, Oxford 1965.

Rorty R., The Priority of Democracy to Philosophy in: M. D. Peterson \& R. C. (eds.), The Virginia Statute for Religious Freedom, Cambridge University Press, Cambridge, MA 1988, pp. 257-284.

Sextus Empiricus, Against the Professors, transl. R. G. Bury, W. Heinemann \& Harvard University Press, London \& Cambridge, MA 1959.

The Sophists and their Legacy, (ed.) Kerferd G. B., Franz Steiner, Wiesbaden 1981.

Wardy R., Mighty Is the Truth, and It Shall Prevail? in: A. Rorty (ed.), Essays on Aristotle's Rhetoric, University of California Press, Berkeley 1996, pp. 56-87. 